\title{
PENGARUH KARAKTER SERTA KEPROFESIONALAN DOSEN DALAM PROSES PERKULIAHAN GUNA MENJADIKAN MAHASISWA YANG CERDAS DAN KRITIS
}

\author{
Muhammad Fahmi Alfarisi \\ Program Studi Pendidikan IPA Jurusan MIPA FKIP Universitas Jember \\ Jalan Kalimantan No. 37 Kampus Tegalboto Sumbersari, Krajan Timur, Sumbersari, Kabupaten \\ Jember, Jawa Timur 68121 \\ email: alfarisimuhammadfahmi@gmail.com
}

\begin{abstract}
Lectures are attended by students and lecturers as facilitators. The success or failure of the lecture process can be measured by the ability of students, both their intellectual abilities and other abilities. The increase of students 'intellectual ability in their fields other than by doing individual learning such as diligent reading and others, the attitude and professionalism of lecturers who teach them is also very influential on students' intellectual development, such as having a teaching strategy that can give students an incentive to think critically and others. However, even though students have high intelligence, the lecturers who teach are not professional, so the lecture process will not last maximally even though the lecturer is only a facilitator.
\end{abstract}

Keyword: lectures, lecturer, and student

\section{PENDAHULUAN}

Perkuliahan adalah jenjang pembelajaran tertinggi yang dilakukan oleh peserta didik. Pada proses perkuliahan ini berbeda pada saat sekolah, di mana proses pembelajaran lebih terpusat kepada pendidik atau guru. Proses perkuliahan diikuti oleh mahasiswa, proses perkuliahan dapat meliputi tatap muka di kelas, praktikum di laboratorium, observasi di luar kampus, dan lain-lainnya. Mahasiswa memiliki kedudukan penting dalam kehidupan berbangsa dan bernegara. Mahasiswa disebut sebagai ujung tombak perubahan bangsa, itu artinya mahasiswa memiliki peran penting dalam perubahan untuk memajukan bangsa ini dalam berbagai bidang.

Saat ini kita hidup di era globalisasi, di mana segala sesuatu terhubung satu sama lain seperti politik, ekonomi, sosial budaya, dan berbagai bidang lainnya. Oleh karena itu, negara yang tidak memiliki keunggulan berbanding dan daya saing yang unggul akan dipastikan tertinggal jauh oleh negaranegara lainnya dan otomatis akan menjadi negara yang terbelakang. Arus globalisasi berlangsung dengan sangat cepat, hal ini dikarenakan banyaknya temuan-temuan di beragai bidang kehidupan seperti teknologi.
Bangsa Indonesia mau tidak mau harus mampu bersaing dengan negara lain pada era globalisasi yang berlangsung sangat deras ini.

Globalisasi berdampak kepada berbagai bidang kehidupan, termasuk dalam bidang pendidikan. Hal ini menuntut kualitas pendidikan di Indonesia harus memiliki mutu yang tinggi, baik sekolahsekolah maupun perguruan tinggi. Pendidikan adalah salah satu sarana untuk menjawab berbagai tantangan yang berkaitan dengan perkembangan informasi, globalisasi, pasar bebas, bahkan masalah kerukunan berbangsa dan bernegara. Pasal 3 Undang-undang No. 2 tahun 1989 tentang Sistem Pendidikan Nasional mengemukakan bahwa pendidikan nasional berfungsi untuk mengembangkan kemampuan serta meningkatkan mutu kehidupan dan martabat manusia Indonesia dalam upaya mewujudkan tujuan nasional. Pendidikan merupakan sesuatu yang berlangsung secara berkelanjutan sejak seseorang masih berada dalam lingkungan keluarga. Proses pembelajaran di perguruan tinggi haruslah bermutu tinggi dan sesuai dengan standar yang telah ditentukan agar mencetak kader-kader mahasiswa yang merupakan tombak pembangunan bangsa.

\section{ScienceEdu Vol. II. No. 2 Desember 2019}


Faktor-faktor penentu mutu kualitan perguruan tinggi dapat ditinjau dari beberapa komponen-komponen yaitu dari kualitas dan mutu akademik, sumber daya manusia, sarana dan prasarana yang tersedia, serta suasana akademik. Berbagai faktorfaktor penunjang mutu dan kualitas tersebut perlu ditingkatkan dalam upaya memenuhi standar nasional pendidikan. Pemerintah dengan Peraturan Pemerintah Nomor 19 Tahun 2005 (Standar Nasional Pendidikan) pasal 2, menyatakan bahwa untuk penyelenggaraan setiap satuan pendidikan harus mengacu delapan standar mutu pendidikan, yakni: standar isi, proses, kompetensi lulusan, pendidik dan tenaga kependidikan, sarana dan prasarana, standar pengelolaan, pembiayaan, dan standar penilaian pendidikan.

Dosen adalah salah satu faktor yang mendukung peningkatan kualitas suatu perguruan tinggi. Sebagaimana hal ini telah ditegaskan dalam Undang-undang Republik Indonesia Nomor 20 Tahun 2003 tentang Sistem Pendidikan Nasional pasal 35 ayat 3 , bahwasanya untuk mencapai mutu standar pendidikan itu tidak hanya ditentukan oleh unsur tenaga kependidikan yakni dosen, tetapi juga bagaimana pengelolaan perguruan tinggi itu atas standar isi, proses, kompetensi lulusan, sarana dan prasarana, pengelolaan, pembiayaan, dan penilaian pendidikan yang dapat dilaksanakan oleh suatu badan standarisasi, penjaminan dan pengendalian mutu pendidikan. DalamUndang-undangRepublik Indonesia Nomor 14 Tahun 2005 tentang Guru dan Dosen, pasal 1 ayat 2 dinyatakan bahwa, "Dosen adalah pendidik profesional dan ilmuwan dengan tugas utama mentransformasikan, mengembangkan, dan menyebarluaskan ilmu pengetahuan, teknologi dan seni melalui pendidikan, penelitian, dan pengabdian kepada masyarakat". Oleh karena itu dosen memiliki kedudukan sebagai agen pengembang pembelajaran, pengembang ilmu pendidikan, teknologi, seni, serta pengabdi kepada masyarakat untuk meningkatkan kualitas pendidikan nasional.

Dosen sebagai pengajar dan pembimbing di perguruan tinggi sangat berpengaruh terhadap baik tidaknya kualitas lulusan yang dihasilkan. Meskipun kualitas yang dihasilkan dari perguruan tinggi tidak selalu bergantung kepada dosen saja, namun dosen tetap memiliki peranan yang cukup besar.

Terdapat dua hal penting yang mencolok pada realitas profesi dosen. Pertama, secara umum masih banyaknya beberapa dosen dari sisi aktivitas hanya mengandalkan kegiatan belajar mengajar sebagai aktivitas primer; selebihnya mereka memilih mencari sampingan berbisnis atau bekerja di sektor lain. Padahal masih ada kewajiban lain bagi para dosen yaitu melakukan aktivitas penelitian dan pengabdian masyarakat, akan tetapi kedua aktivitas tersebut sulit dilaksanakan dan tertinggalkan. Dosen juga merupakan salah satu dari beberapa faktor yang dituntut untuk memiliki peran dalam penjaminan kualitas, terutama dalam proses belajar mengajar. Jika profesionalisme dosen dapat terdeteksi dengan baik tentu akan juga diketahui sejauh mana para dosen bertanggung jawab dalam penjaminan mutu.

Dalam dunia perkuliahan, dosen memiliki peran penting dan peran yang strategis ditinjau dari sisi pembinaan akademik dan mahasiswa. Dosen merupakan tenaga profesional yang menetapkan apa yang terbaik untuk mahasiswanya berdasarkan pertimbangan profesional. Banyak pengakuan yang menyatakan bahwa pengembangan mutu pendidikan dapat ditempuh melalui pengembangan mutu dosen. Sehingga apabila ada seorang dosen yang tidak memiliki keprofesionalan dalam membimbing mahasiswanya, maka dosen tersebut bisa dikatakan tidak berhasil dalam memainkan perannya sebagai agen pengembang ilmu pendidikan. Padahal seperti yang kita ketahui, dosen memiliki peran yang sangat vital dalm dunia pendidikan, terutama dalam mendidik mahasiswa yang notabenenya adalah sebagai tombak perubahan bangsa. 


\section{METODE PENELITIAN}

Penelitian yang dilakukan in yaitu dengani menggunakan metode studi literatur, di mana penelitian yang dilakukan merupakan pengumpulan sejumlah sumbersumber dan beberapa referensi teori yang relefan dengan kasus atau permasalahan yang ditemukan baik berupa buku-buku ilmiah, laporan penelitian, karangankarangan ilmiah, tesis dan disertasi, peraturan-peraturan, ketetapan-ketetapan, buku tahunan, ensiklopedia dan sumbersumber tertulis baik tercetak maupun elektronik lain yang berkaitan dengan masalah dan tujuan penelitian. Teknik pengumpulan sumber-sumber dan beberapa referensi teori yang relefan ini dilakukan dengan tujuan untuk mengungkapkan berbagai teori-teori yang relevan dengan permasalahan yang sedang dihadapi ataupun diteliti sebagai bahan rujukan dalam pembahasan hasil penelitian.

Studi kepustkaan adalah sebuah kegiatan yang tidak dapat dipisahkan dari suatu penelitian. Teori-teori yang mendasari masalah dan bidang yang akan diteliti dapat ditemukan dengan melakukan studi kepustakan. Selain itu dalam melakukan penelitian haruslah dapat memperoleh informasi tentang penelitian-penelitian sejenis atau yang ada kaitannya dengan penelitiannya. Dan penelitian-penelitian yang telah dilakukan sebelumnya. Dengan melakukan studi kepustakan peneliti dapat memanfaatkan semua informasi dan pemikiran-pemikiran yang relevan dengan penelitiannya.

Dalam studi kepustakan, terdapat sitematis tentang kajian literatur dan hasil penelitian sebelumnya yang ada hubungannya dengan penelitian yang akan dilakukan dan diusahakan menunjukkan kondisi mutakhir dari bidang ilmu tersebut "the state of the art", studi kepustakaan yang dilakukan sebelum malakukan penelitian yang bertujuan untuk menemukan suatu masalah untuk diteliti, dalam arti bukti-bukti atau pernyataan bahwa masalah yang akan diteliti belum terjawab atau belum terpecahkan secara memuaskan atau belum pernah diteliti orang mengenai tujuan, data dan metode, analisa dan hasil untuk waktu dan tempat yang sama, mencari informasi yang relevan dengan masalah yang akan diteliti, serta mengkaji beberapa teori dasar yang relevan dengan masalah yang akan diteliti, menggali teori-teori yang relevan dengan permasalahan penelitian dan melakukan komparasi-komparasi dan menemukan konsep-konsep yang relevan dengan pokok masalah yang dibahas dalam penelitian.

Penelitian juga dilakukan dengan melakukan interview khusus dengan beberapa mahasiswa di Fakultas Keguruan dan Ilmu Pendidikan Universitas Jember. Mahasiswa yang diwawancari merupakan dari program studi yang berbeda-beda. Dari beberapa mahasiswa yang diwawancarai, mereka mengungkapkan bahwasanya dosen memiliki peran yang sangat penting dalam membangun suasana di kelas, agar mahasiswa memiliki semangat serta motivasi untuk belajar, dosen juga memiliki peran untuk menjadikan mahasiswa di kelas dapat menyerap beberapa materi yang disampaikan dosen, walaupn mahasiswa tetap diwajibkan untuk aktif di dalam kelas.

\section{PEMBAHASAN}

Peranan dosen dalam proses perkuliahan nyatanya sangatlah besar, selain menjadikan mahasiswa sebagai tombak kepemimpinan serta perubahan, dosen juga memiliki peranan penting sebagai pengembang ilmu pendidikan, pengembang teknologi, serta pengabdi kepada masyarakat. Dari hasil wawancara yang diperoleh, dosen yang memiliki cara mengajar dan sikap yang ramah dan friendly kepada mahasiswa yang dibimbingnya akan memunculkan suasana yang nyaman dalam perkuliahan, sehingga mahasiswa tidak merasa bosan serta memunculkan rasa semangat untuk aktif dalam proses perkuliahan. Seperti yang dapat kita ketahui, dalam dunia perkuliahan sebenarnya dosen adalah fasilitator dan mahasiswa dituntut aktif dan mandiri dalam pembelajaran, akan tetap keprofesionalan dosen dalam membimbing mahasiswanya sangatlah berpengaruh dalam mencetak 
mahasiswa yang cerdas, kritits, serta tanggap dalam menyelesaikan permasalahan yang terjadi.

Terdapat tiga komponen yang sangat penting dalam proses pembelajaran, yaitu: (1) siswa atau mahasiswa dengan karakteristik yang dimilikinya, baik dari dalam diri atau dari luar dirinya, (2) tujuan yang merupakan apa yang diinginkan serta diharapkan dari adanya proses pembelajaran, merupakan seperangkat tugas atau tuntutan yang harus nampak dalam perilaku dan merupakan karakteristik kepribadian siswa, dan (3) guru atau dosen yang merupakan orang dewasa yang karena jabatannya secara formal selalu mengusahakan terciptanya situasi yang tepat sehingga memungkinkan terciptanya proses learning experience pada siswa dengan mengerahkan segala learning resource dan menggunakan teachinglearning strategy yang tepat. Dalam praktiknya, untuk mencapai proses pembelajaran yang tepat, dosen perlu menentukan strategi yang sesuai.

Adapun teknik pembelajaran memiliki arti sebagai sebuah cara yang dilakukan seseorang dalam mengekspresikan suatu metode dengan cara yang spesifik. Misalkan, dalam proses perkuliahan, penggunaan metode ceramah pada kelas dengan jumlah siswa yang relatif banyak membutuhkan teknik serta strategi tersendiri, yang tentunya secara teknis akan berbeda dengan penggunaan metode ceramah pada kelas yang jumlah siswanya terbatas. Sama halnya dengan penggunaan metode diskusi, perlu digunakan teknik yang berbeda pada kelas yang siswanya tergolong aktif dengan kelas yang siswanya tergolong pasif. Dalam hal ini, dosen dapat berganti-ganti teknik meskipun dalam koridor metode yang sama. Hasil penelitian menunjukkan bahwa kesadaran pandangan positif pada umpan balik dari dosen dan mahasiswa aktif mencari informasi baru, merupakan aspek dalam motivasi belajar yang signifikan, artinya aspek ini menjadi motivasi mahasiswa untuk mencapai prestasi yang baik dalam proses pembelajaran. Gaya mengajar dosen dan motivasi belajar berpengaruh positif terhadap hasil belajar. Sedangkan hasil penelitian menunjukkan karakteristik dosen dan motivasi belajar berpengaruh positif dan signifikan terhadap kedisiplinan belajar. Berdasarkan analisis data yang ditemukan bahwasanya variabel budaya organisasi memiliki kontribusi terbesar terhadap peran dosen dalam penjaminan kualitas $(50,41 \%)$. Hal ini merupakan suatu kewajaran dikarenakan budaya organisasi yang baik pada hakikatnya merupakan kekuatan yang dapat menyatukan tujuan, menciptakan motivasi, komitmen, dan loyalitas seluruh dosen, serta memberikan struktur dan kontrol yang dibutuhkan tanpa harus bersandar pada birokrasi formal. Budaya organisasi dapat meningkatkan motivasi dan inovasi yang berdampak pada meningkatnya peran dosen dalam penjaminan mutu perguruan tinggi.

Secara simultan, variabel-variabel eksogen memberikan kontribusi sebesar 95\% terhadap peran dosen dalam penjaminan kualitas. Hal ini dimaklumi karena dalam penelitian ini mencakup banyak variabel yang secara teoretis menggambarkan keseluruhan faktorfaktor penyebab peran dosen dalam penjaminan mutu. Faktorfaktor itu bisa berasal dari dalam diri dosen, faktor dari organisasi, dan faktor eksternal. Berkaitan dengan peran dosen dalam penjaminan mutu perguruan tinggi, faktor dari dalam diri dosen itu adalah kompetensi dan motivasi berprestasi. Adapun faktor yang berasal dari organisasi adalah kepemimpinan dan budaya organisasi.

Dari hasil data yang diperoleh, peran dosen dalam pembimbingan akademik cukup tinggi yaitu $94,73 \%$, sedangkan yang tidak aktif hanya $5,26 \%$ saja. Hal ini menunjukkan bahwa dosen dalam melayani mahasiswa dalam pembimbingan akademik cukup baik, karena pelayanan kepada mahasiswa merupakan tugas pokok dosen.

Peningkatan peran dosen dalam penjaminan kualitas di perguruan tinggi haruslah dilaksanakan dalam rangka meningkatkan kualitas pendidikan tinggi. Tercapainya kinerja lembaga dalam pelaksanaan penjaminan mutu merupakan salah satu bentuk keberhasilan perguruan tinggi dalam mengelola sumberdaya 
manusia yang dimiliki. Kualitas pendidikan tinggi adalah tercapainya tujuan pendidikan dan kompetensi lulusan sesuai dengan standar yang ditetapkan.

Proses penjaminan mutu di perguruan tinggi tergantung dari orientasi tindakan pengembangan visi dan misi pimpinan. Hal ini diperlukan karena pendidikan itu selalu berubah setiap saat. Untuk merumuskan visi perlu proses interaksi antar warga kampus. Perumusan visi adalah tugas manajemen tingkat atas tetapi harus merupakan proses interaksi yang memberikan peluang untuk mendapatkan umpan balik dari semua tingkat manajemen, yakni: rektor, dekan, dosen, staf karyawan, dan mahasiswa. Pimpinan perguruan tinggi perlu menunjukkan komitmen kuat dan terusmenerus dalam memimpin sekaligus mendorong para dekan, ketua jurusan, dan dosen untuk melakukan usaha secara serius dalam rangka mewujudkan mutu perguruan tinggi.

Beberapa kriteria kualitas kepemimpinan yang baik antara lain, memiliki komitmen organisasional yang kuat, visionary, disiplin diri yang tinggi, tidak melakukan kesalahan yang sama, antusias, berwawasan luas, kemampuan komunikasi yang tinggi, manajemen waktu, mampu menangani setiap tekanan, mampu sebagai pendidik atau guru bagi bawahannya, empati, berpikir positif, memiliki dasar spiritual yang kuat, dan selalu siap melayani.

Adanya pengaruh yang bermakna dari masa kerja, trait kepribadian, kepuasan kerja, dan iklim psikologis terhadap komitmen dosen pada universitas menunjukkan bahwa faktor pribadi dan faktor lingkungan secara bersama-sama mempengaruhi komitmen dosen pada universitas. Ini berarti, walaupun faktor individu memiliki peran penting dalam pembentukan komitmen pada universitas, faktor lingkungan juga memainkan peran yang menentukan.

Kompetensidosen memberikan kontribusi terhadap peran dosen dalam penjaminan mutu $(8,41 \%)$. Kekuatan utama kehidupan perguruan tinggi terletak pada kekuatan para dosen. Seorang dosen dapat meningkatkan perannya dalam proses penjaminan mutu perguruan tinggi apabila dosen yang bersangkutan memiliki kompetensi yang memadai. Semakin baik kompetensi dosen akan semakin profesional dalam melakukan tugas. Peningkatan kompetensi dosen ini dapat dilakukan melalui pengembangan kompetensi.

Indikasi dosen yang memiliki motivasi berprestasi tinggi dapat dijadikan sebagai kerangka acuan dalam upaya memperkuat motif berprestasi dosen yang ditunjukkan oleh keyakinan serta tindakannya dalam beberapa aspek meliputi tanggung jawab pribadi, tujuan yang rasional, kesungguhan dalam bekerja, menyukai pekerjaan yang menantang, dan keinginan mendapat umpan balik. Dengan demikian dosen yang memiliki motivasi berprestasi tinggi memiliki ekspektasi yang cukup besar dan semakin tinggi pengorbanan yang diberikan dalam meningkatkan mutu perguruan tinggi

Adanya pengaruh langsung yang positif dan bermakna dari kepuasan kerja terhadap komitmen dosen pada universitas menunjukkan bahwa semakin tinggi kepuasan dosen terhadap pekerjaannya, maka semakin tinggi pula keterikatan pada universitas. Kepuasan kerja ini terutama dirasakan dalam hal kepuasan terhadap pimpinan fakultas, kepuasan terhadap rekan kerja, kepuasan terhadap komunikasi yang terjadi di dalam fakultas, serta kepuasan terhadap kondisi kerja yang tersedia di fakultas.

Untuk meningkatkan rasa nyaman pada dosen, khususnya dalam hal kondisi beserta suasana kerja, maka pihak universitas memiliki keharusan untuk menyediakan berbagai sarana dan prasarana yang mendukung berlangsungknya kegiatan-kegiatan tridharma perguruan tinggi, misalnya dengan menyediakan perpustakaan dengan koleksi buku yang lengkap, buku-buku terbaru dan ruang baca yang membuat pengunjung nyaman dan betah, akses internet yang luas, lancar dan cepat, komputer dengan berbagai program aplikasi terbaru dan terupdate, peralatan mengajar yang lengkap dan memadai serta 
kondisinya terawat, ruang rapat atau diskusi yang menunjang, serta ruang kerja yang nyaman dan kondusif untuk bekerja. Selain itu, fasilitas-fasilitas yang juga diperlukan untuk meningkatkan kesehatan jasmani dan kesejahteraan psikologis dosen antara lain fasilitas olah raga, ruang istirahat, serta pusat kesehatan bagi dosen.

Salah satu faktor yang berkaitan dengan kepuasan kerja dosen yang pada akhirnya dapat memperngaruhi komitmen dosen pada universitas adalah kepuasan terhadap komunikasi. Bentuk komunikasi ini dapat ditingkatkan melalui media komunikasi tertulis seperti buletin serta pertemuan langsung yang bersifat komunikasi dua arah antara pimpinan fakultas dan universitas dengan dosen dimana dosen dapat memberikan kritik dan masukan bagi pimpinan fakultas dan universitas.

Ditemukannya pengaruh yang bermakna dari usia dan lama kerja terhadap komitmen dosen pada universitas menunjukkan bahwa dosen yang memiliki masa kerja yang lebih panjang akan memiliki komitmen yang lebih tinggi terhadap universitas. Hal ini terjadi karena semakin tinggi usia dosen serta semakin lama dosen bekerja di universitas maka dosen tersebut semakin mencintai pekerjaannya serta mencintai Universitas Indonesia sehingga bersedia untuk terus terlibat dalam kegiatan fakultas dan universitas. Semakin lama seseorang bekerja dalam satu organisasi maka semakin tinggi pula kepuasannya terhadap pekerjaan. Dengan demikian, komitmen yang tinggi pada dosen yang lebih lama bekerja dapat disebabkan oleh adanya kepuasan kerja yang tinggi. Kepuasan ini diperoleh antara lain dari adanya kesesuaian antara apa yang diharapkan dengan apa yang diterima dosen, antara adanya minat yang tinggi terhadap pendidikan dan pengajaran dengan kesempatan untuk berinteraksi dengan mahasiswa, serta antara keinginan untuk mengembangkan diri dan mengembangkan ilmu pengetahuan dengan adanya kesempatan untuk melanjutkan pendidikan ke jenjang yang lebih tinggi atau mengikuti berbagai seminar nasional dan internasional.

\section{SIMPULAN}

Perkuliahan adalah jenjang pembelajaran tertinggi yang dilakukan oleh peserta didik. Pada proses perkuliahan ini berbeda pada saat sekolah, di mana proses pembelajaran lebih terpusat kepada pendidik atau guru. Proses perkuliahan diikuti oleh mahasiswa, proses perkuliahan dapat meliputi tatap muka di kelas, praktikum di laboratorium, observasi di luar kampus, dan lain-lainnya. Mahasiswa memiliki kedudukan penting dalam kehidupan berbangsa dan bernegara. Mahasiswa disebut sebagai ujung tombak perubahan bangsa, itu artinya mahasiswa memiliki peran penting dalam perubahan untuk memajukan bangsa ini dalam berbagai bidang.

Dosen adalah pendidik yang professional dan seorang ilmuan yang memiliki tugas utama untuk memodifikasi, mengembangkan dan menyebarkan ilmu pengetahuan, teknologi, serta kesenian melalui bidang pendidikan, penelitia, serta pengabdian kepada masyarakat. Para dosen haruslah memiliki kesadaran akan pentingnya peran dalam menjalankan tugas dan fungsi utamanya dalam dunia perguruan tinggi. Namun itu semua haruslah didukung oleh para tenaga pendidikan, sarana dan prasarana, serta bermacam program akademik ataupun program non akademik.

\section{SARAN DAN UCAPAN TERIMA}

\section{KASIH}

Saran yang disampaikan ialah dosen harus memaksimalkan perannya sebagai pengembang dan penyebar ilmu pengetahuan, teknologi, seni, dan bidangbidang lainnya. Para dosen haruslah memiliki kesadaran akan pentingnya peran dalam menjalankan tugas dan fungsi utamanya dalam dunia perguruan tinggi

\section{DAFTAR PUSTAKA}


Anjaningrum, Widiya Dewi. (2017). Pengaruh Karakter Dosen dan Teknik Pembelajaran Terhadap Motivasi Mahasiswa Mengikuti Perkuliahan Matematika Ekonomi dan Bisnis (Studi pada Mahasiswa STIE ASIA Malang Tahun Ajaran 2015-2016).

Seniati, Liche. (2006). Pengaruh Masa Kerja, Trait Kepribadian, Kepuasan Kerja, dan Iklim Psikologis Terhadap Komitmen Dosen pada Universitas Indonesia. Makara, Sosial Humaniora, Vol. 10, No. 2.

Sumardjoko, Bambang. (2010). FaktorFaktor Determinan Peran Dosen Dalam Penjaminan Mutu Perguruan Tinggi. Jurnal Cakrawala Pendidikan, Th. XXIX, No. 3.

Wijoyo, Mardi. (2009). Profesionalisme Dosen Dalam Program Penjaminan Mutu. Jurnal Pendidikan, Jilid 16, No. 1 .

Winarni, Sri. (2013). Integrasi Pendidikan Karakter dalam Perkuliahan.Jurnal Pendidikan Karakter, Tahun III, Nomor 1. 